\title{
Water use in four model tropical plant associations established in the lowlands of Costa Rica
}

\author{
Marco V. Gutiérrez-Soto ${ }^{1}$ \& John J. Ewel ${ }^{2,3}$ \\ 1. Universidad de Costa Rica, Estación Experimental Agrícola Fabio Baudrit, P.O. Box 183-4050 Alajuela, Costa Rica; \\ surdo26@racsa.co.cr \\ 2. USDA Forest Service, Institute of Pacific Island Forestry, Honolulu, HI USA. \\ 3. Present address: Department of Biology, University of Florida, Gainesville, FL 32611, USA; jackewel@ufl.edu
}

Received 14-IX-2007. Corrected 08-V-2008. Accepted 31-VII-2008.

\begin{abstract}
We examined soil water use patterns of four model plant associations established in the North Caribbean lowlands of Costa Rica by comparing the stable hydrogen isotope composition, $\delta \mathrm{D}$, in xylem sap and in soil water at different depths, under rainy and dry conditions. Four 5-year-old model plant associations composed of 2 tree species (Hyeronima alchorneoides and Cedrela odorata) having different architecture and phenology were studied. Average tree height was 8.9 and $7.6 \mathrm{~m}$, respectively. Each tree species was grown in monoculture and in polyculture with 2 perennial monocotyledons (Euterpe oleracea and Heliconia imbricata). Maximum rooting depth at the time of $\delta \mathrm{D}$ determination was $\sim 2 \mathrm{~m}$ for almost all species. Most roots of all species were concentrated in the upper soil layers. Stomatal conductance to water vapor $\left(\mathrm{g}_{\mathrm{S}}\right)$ was higher in the deciduous $C$. odorata than in the evergreen $H$. alchorneoides; within each species, $\mathrm{g}_{\mathrm{S}}$ did not differ when the trees were grown in mono or in polyculture. During the rainy season, gradients in soil water $\delta \mathrm{D}$ were not observed. Average rainy season xylem sap $\delta \mathrm{D}$ did not differ among members of the plant combinations tested $(-30 \%)$, and was more similar to $\delta \mathrm{D}$ values of shallow soil water. Under dry conditions, volumetric soil water content declined from 50 to $\sim 35 \%$, and modest gradients in soil water $\delta \mathrm{D}$ were observed. Xylem sap $\delta \mathrm{D}$ obtained during dry conditions was significantly lower than rainy season values. Xylem sap $\delta \mathrm{D}$ of plants growing in the four associations varied between -9 and $-22 \%$, indicating that shallow water was predominantly absorbed during the dry period too. Differences in xylem sap $\delta \mathrm{D}$ of trees and monocots were also detected, but no significant patterns emerged. The results suggest that: a) the plant associations examined extracted water predominantly from shallow soil layers $(<1 \mathrm{~m})$, b) the natural isotopic variation in soil and plant water at the study site was low, and c) the plant mixes obtain water from more than a single soil layer simultaneously. Temporal factors were important in determining the competition and complementary relations observed among the trees and the perennial monocots. Under the prevailing environmental conditions, water use in these plant associations was determined largely by species-specific attributes such as biomass allocation to fine roots, phenology, and canopy architecture, and to a lesser extent by water limitations. Rev. Biol. Trop. 56 (4): 1947-1957. Epub 2008 December 12.
\end{abstract}

Key words: Cedrela odorata, Heliconia imbricata, Euterpe oleracea, Hyeronima alchorneoides, monoculture, polyculture, tropical agro-ecosystem design, water isotopes.

Below-ground processes, such as extraction of soil water and competition for water resources, remain the least understood aspects of plant interactions that determine the success of land use systems in the tropics (Sánchez 1976, Gliessman 1986, Ong 1995). This is partly due to the slow progress in understanding the underground components of key biogeochemical cycles and the structural and functional diversity of root systems of tropical plants, which very likely parallels that of the above-ground shoot components.

Establishing the biological basis of these interactions is important because efficient and complementary use of resources is a major criterion in the selection of species for tropical 
reforestation, and in the design of sustainable tropical agro-ecosystems (Ewel 1986, Pate and Dawson 1999). Plant life forms, life spans, and natural history traits are key components of the design of sustainable land use systems in the tropics (Ewel 1986, 1999). Diversity in these characteristics can be expressed in greater stability, resilience and resistance to perturbations, with implications for the sustainability and stability of productivity, including food and fiber production. Species with contrasting life history, phenology, and resource capture strategies may co-exist because they differ in traits like root architecture and resource allocation to roots that facilitate access to different soil layers (Nepstad et al. 1994, Pate and Dawson 1999, Moreira et al. 2000, Sternberg et al. 2002).

Natural as well as managed traditional tropical ecosystems are composed of combinations of plant life forms that have the potential to be more productive and more thorough in the use of resources than most monocultures (Haggar and Ewel 1995, 1997). It has been hypothesized that full use of resources on a site having high potential productivity could be achieved by the use of highly productive monocultures or the combination of productive species that complement one another in their use of resources (Haggar and Ewel 1997). Greater productivity of plant associations seems to be due to the combination of trees with species that occupy other layers of the canopy and soil. Examples of this are combinations of trees with understory plants and perennial monocots. Trees allocate a high proportion of their biomass to supporting structures, while many perennial monocots show high allocation to structures such as leaves and fine roots (Haggar and Ewel 1997). These species may be complementary in the use of key resources and be successfully used to construct sustainable land use systems.

Scarcity of water is not usually considered a constraint for plant and ecosystem functioning in tropical wet forests (Swaine 1996, Whitmore 1996). Abundant studies show, however, the significant impact that short dry periods may have on the survival of plant and animal species (Wright et al. 1999, Engelbrecht et al. 2006), above- and below-ground plant phenology (Ceccon et al. 2006) and on postdrought succession (see Mesquita 2001) in these ecosystems. Competition for water may be exacerbated in monocultures or mixtures of species having roots that require access to the same pool of soil resources (Pate and Dawson 1999).

Studies of hydrogen and oxygen stable isotope ratios of water within plants and in soils have become an important tool in belowground studies (Walker and Richardson 1991, Thorburn and Ehleringer 1995, Sternberg et al. 2002). Natural differences in the water isotopic signature along the soil profile and between soil and ground water can be used to indicate depth of acquisition of water and other key soil resources. These studies have provided new information on competitive interactions and water use patterns of plants in natural and agricultural conditions (Walker and Richardson 1991, Ehleringer and Dawson 1992, Ehleringer and Osmond 1999, Dawson et al. 2002). They have also revealed the sources of water utilized by different life forms in various environments (Dawson and Ehleringer 1991, Jackson et al. 1995, 1999, Meinzer et al. 1995, 1999, Pate and Dawson 1999, Stratton et al. 2000, Drake and Franks 2003), and the mechanisms involved in the control of water balance (Dawson 1993, Goldstein et al. 1996). Further application of these techniques have been conducted at sites where the depth of water uptake varies seasonally (Sternberg et al. 2002), and at very wet riparian tropical environments, where soil water partitioning among different life forms may occur only during the dry season (Drake and Franks 2003).

We hypothesized that combinations of life forms may partition water resources in time and space, thus leading to complementary water use in model tropical plant associations, planted in the tropical lowlands of Northern Costa Rica. To test this hypothesis, we examined the pattern of soil water utilization by several combinations of trees and perennial monocots, using the relative 
abundance of natural isotopes of water, and explored the degree of complementary water use displayed by these plant combinations under wet and dry conditions.

\section{MATERIALS AND METHODS}

\section{Experimental site and plant materi-} al: The study was conducted at La Selva Biological Station in Sarapiquí $\left(10^{\circ} 26^{\prime} \mathrm{N}\right.$, 8359'W), Heredia, Costa Rica, during 19961997. La Selva tropical wet forest is located in the Atlantic lowlands of Costa Rica, at $c a$. $35 \mathrm{~m}$ above sea level; annual rainfalls is $\sim 4$ $\mathrm{m}$ and mean temperature is $26^{\circ} \mathrm{C}$ (McDade et al. 1994). Rainfall distribution is controlled by the migration of the inter-tropical convergence zone; February through April are the driest months $(152,162$ and $255 \mathrm{~mm}$ of rain, respectively), but a brief dry period also occurs in September-October. Details on the establishment and the characteristics of the field site are given in Haggar and Ewel (1995, 1997). Briefly, the experiment was established in 1991 on an alluvial terrace with a deep, well drained, fertile soil that allowed the extraction of soil samples from depths $>2 \mathrm{~m}$. Plantations (60x40 m stands) of two fast-growing trees (Hyeronima alchorneoides and Cedrela odorata) were selected. The trees were planted in rows $1.73 \mathrm{~m}$ apart with $2 \mathrm{~m}$ between trees within rows, and the planting within each row was offset by $1 \mathrm{~m}$ from the rows either side, so that each tree was surrounded by 6 other trees, each 2 m away. At the time of this study, stand density was 2887 trees $\mathrm{ha}^{-1}$ and each tree occupied a hexagonal area of $3.46 \mathrm{~m}^{2}$. The tree species were selected on the basis of their phenological and architectural differences (Hiremath 2000). H. alchorneoides is an evergreen, dense-canopied species having high fine-root density, while $C$. odorata is deciduous, open-crowned, and has relatively low fineroot density. H. alchorneoides trees were $8.9 \pm$ $1.1 \mathrm{~m}$ and $C$. odorata trees were $7.6 \pm 2.3 \mathrm{~m}$ tall at the time of the study.

Four plant associations were examined: C. odorata growing in mono (CeMo) and in polyculture (CePo), and H. alchorneoides growing in mono (HyMo) and in polyculture (HyPo) with a combination of two perennial monocots, $H$. imbricata $(\mathrm{He})$ and E. oleracea (Eu). There were three stands (blocks) of each tree species. Each stand was split in two parts, each of which was $30 \times 40 \mathrm{~m}$. One part was maintained as a tree monoculture, while the other part was inter-planted with two perennial monocots, Euterpe oleracea and Heliconia imbricata, two large-stature, self-supporting monocotyledons. E. oleracea was planted at the same time as the trees, between every other row of trees. One year later, $H$. imbricata was added to intensify the monocot-dicot interaction; it was planted between all the trees in the rows where E. oleracea had not been planted (Haggar and Ewel 1995, 1997). Such additive designs are recommended by Snaydon (1991) to test the occurrence of complementary use of resources.

\section{$\delta D$ sampling and measurement in soils} and plants: Soil and plant tissue samples for water isotopic analysis were taken on Nov. 14-15, 1996, and again on Apr. 10-15, 1997. The 1996 sampling was conducted under rainy conditions. The April 1997 sampling was conducted shortly before the end of a pronounced dry period (that typically occurs around this time at La Selva, McDade et al. 1994). Root excavation and soil coring revealed that the root systems of all species extended to a maximum depth of $2 \mathrm{~m}$, except in H. imbricata in the $H$. alchorneoides polyculture, whose roots penetrated only to $0.6 \mathrm{~m}$. Soil samples were collected every $20 \mathrm{~cm}$ using a Dutch auger during the rainy season and every $50 \mathrm{~cm}$ during the dry period monitored. Three soil samples were taken at each depth, one from each block. The samples were quickly transferred to plastic vials, hermetically sealed and frozen at $-50{ }^{\circ} \mathrm{C}$ until further distillation.

The water-conducting xylem of the tree species and the perennial monocotyledons was determined through dye uptake tests (acid fuchsine, $1 \%$ ) prior to the sampling for tissue water isotopic composition (see Gutiérrez and 
Santiago 2006). Six trees were sampled within each treatment; two samples were taken from each tree, at opposite sides of the stem. For monocotyledons, sections of the rachis of six young, fully expanded leaves within each treatment were collected. The samples were quickly transferred to cryogenic vials, hermetically sealed and stored frozen until distillation.

Distillations were conducted at the "Centro de Investigaciones en Productos Naturales" (CIPRONA), University of Costa Rica, in a distillation apparatus designed to operate 8 elbow-shaped mini-distillation apparatuses (Aldrich Sci.) under partial vacuum and a steep temperature gradient $\left(110\right.$ to $\left.-40{ }^{\circ} \mathrm{C}\right)$, based on the designs of Thorburn et al. (1993) and Jackson et al. (1995). The capacity of the distillation system to recover the water extracted from the samples was assessed gravimetrically through control tests performed on parallel sets of samples. Distilled water samples were sent to the Stable Isotope Laboratory at Boston University, where the stable hydrogen isotopic composition was determined. This is expressed in delta notation $(\delta)$ as the $\mathrm{D} / \mathrm{H}$ ratio relative to V-SMOW standard (Ehleringer and Osmond 1989):

$$
\delta(\%)=\left(\mathrm{R}_{\text {sample }} / \mathrm{R}_{\text {standard }}-1\right) \times 1000
$$

Soil water content: Volumetric soil water content to a depth of $1 \mathrm{~m}$ during the experimental period was measured using a time domain reflectometer (TDR, Trase system 6050X1, SoilMoisture, CA). TDR determines the average dielectric constant, which was converted to volumetric water content using an empirical relation for soils (Topp et al. 1980).

Stomatal conductance measurements: Scaffolds were used to access the canopy of at least 4 trees of each species. Six fully expanded sun leaves located in the upper canopy of each tree were labeled. Stomatal conductance $\left(\mathrm{g}_{\mathrm{S}}\right)$ was measured on different occasions during the rainy season, using a steady-state porometer (Model 1600; Li-Cor, Inc., Lincoln, NE). Stomatal conductance was measured on six different days in $H$. alchorneoides mono and polycultures, and on two days in $C$. odorata mono- and polycultures. Because of typical weather patters at La Selva, most $g_{S}$ measurements were obtained during the early morning hours.

Statistical analyses: Statistical analyses were performed using SAS v.7 for Windows (SAS Institute Inc., 1998, NC, USA) after testing to ensure that assumptions of normality and homogeneity of variance were met (Little et al. 1992) and applying a t-test to the comparisons made. Single-factor analyses of variance were used to compare: a) $\mathrm{g}_{\mathrm{S}}$ measurements of $H$. alchorneoides and C. odorata grown in mono and polyculture, $b$ ) the isotopic signature of xylem water extracted from different tree and monocot species, during the rainy and dry seasons, when trees where grown in mono- and polycultures, c) the isotopic signatures of soil water down the soil profile within each sampling season, and d) differences in soil water isotopic signatures obtained during the dry and rainy seasons.

\section{RESULTS}

\section{Water isotopic composition and water use}

Soil: The dry period sampling was conducted near the end of a 3-week-long drought during which volumetric soil water content at the field site declined from $\sim 50 \%$ to $30-35 \%$ (Fig. 1) and wilting of many plants was evident. Soil water $\delta D$ values obtained at the end of this dry period (Fig. 2) were higher near the soil surface $(-15 \%)$ and decreased with increasing depth; the lowest $\delta \mathrm{D}$ values were typically found at a depth of $2 \mathrm{~m}(-35 \%)$. Despite the development of an incipient gradient in soil water $\delta \mathrm{D}$, variations at each depth down the soil profile resulted in non-significant statistical differences among the soil depths sampled $(p<0.05)$. Rainy season soil water $\delta D$ values fall within the ranges measured in other tropical forests (Jackson et al. 1995, 1999, Meinzer et al. 1999, Dawson et al. 2002). During the 


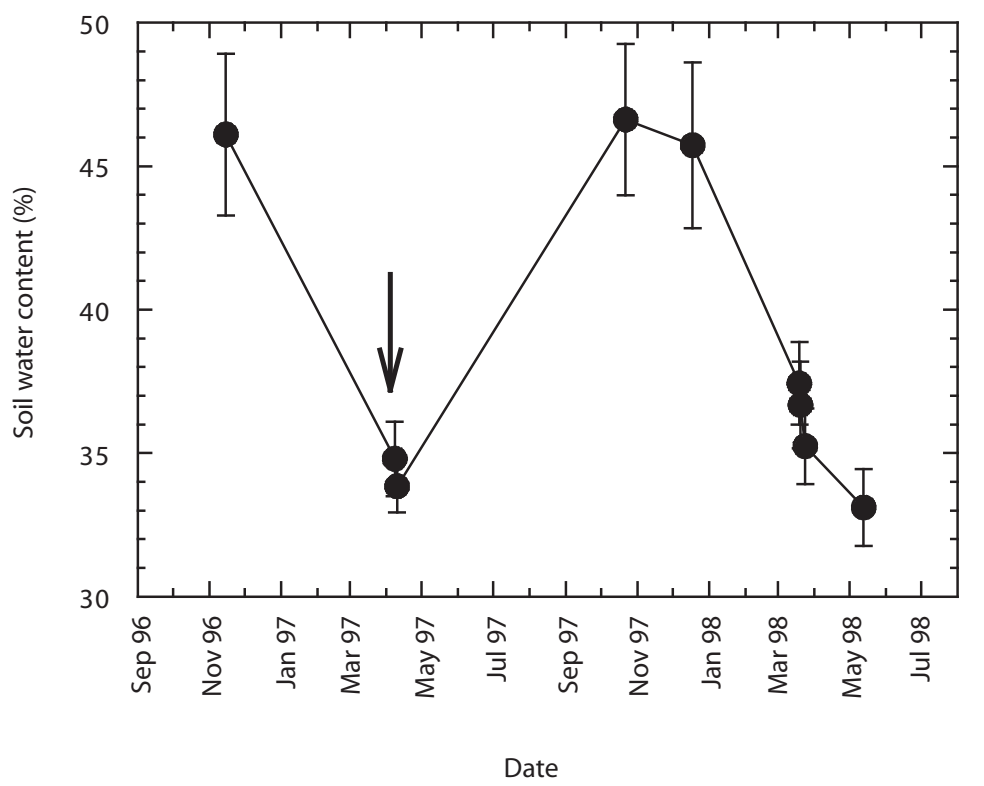

Fig. 1. Soil water content at the field site during wet and dry periods measured with a TDR at $1 \mathrm{~m}$ depth. The arrow shows soil water content at the time of $\delta \mathbf{D}$ sampling (Apr. 10-15, 1997) near the end of a 3-week-long dry period at La Selva.

rainy season, volumetric soil water content was $40-50 \%$ within the first meter of soil, and soil water $\delta \mathrm{D}$ profiles did not reveal significant gradients in isotopic composition $(\mathrm{p}<0.05)$ (Fig. 2 ). Typical rainy season soil water $\delta D$ values ranged between -20 and $-50 \%$ and fluctuated down the soil profile, but did not seem to be related to soil depth or water content.

Plants: Xylem sap $\delta D$ values differed significantly between the rainy and dry periods $(\mathrm{p}<0.05)$ (Fig. 3). No differences in access to soil water sources (as reflected in xylem sap) were observed between trees and monocots during the rainy season $(\mathrm{p}<0.05)$. Rainy season xylem sap values were consistently lower than dry season values and ranged approximately from -26 (H. imbricata in C. odorata) to $-36 \%$ (C. odorata in polyculture). Dry period values ranged from -8 (C. odorata monoculture) to $-24 \%$ ( $C$. odorata in polyculture). Only during the dry period, tree xylem sap $\delta D$ showed significantly lower values than monocot xylem sap $\delta D(p<0.05)$. Within each season, xylem sap $\delta \mathrm{D}$ values did not differ between the two tree species examined when growing in monoculture or in polyculture $(p<0.05)$. The presence of the monocotyledons did not affect the pattern of soil water use by the two tree species, nor were patterns of soil water use by the two monocots affected by the presence of either tree species.

Stomatal conductance: Stomatal conductance $\left(\mathrm{g}_{\mathrm{S}}\right)$ values varied little during the measurement periods, which usually spanned from 7 am to mid-day. Values of $\mathrm{g}_{\mathrm{S}}$ of the deciduous C. odorata $\left(\approx 0.5 \mathrm{~mol} \mathrm{~m}^{-2} \mathrm{~s}^{-1}\right)$ were significantly higher $(\mathrm{p}<0.05)$ than $\mathrm{g}_{\mathrm{S}}$ of the evergreen $H$. alchorneoides $\left(<0.25 \mathrm{~mol} \mathrm{~m}^{-2} \mathrm{~s}^{-1}\right)$ (Fig. 4). No differences in $g_{S}$ were observed within the two tree species examined when the trees were grown in mono- or in polyculture $(\mathrm{p}<0.05)$.

\section{DISCUSSION}

The results of this study show that gradients in soil water $\delta \mathrm{D}$ may develop in tropical 


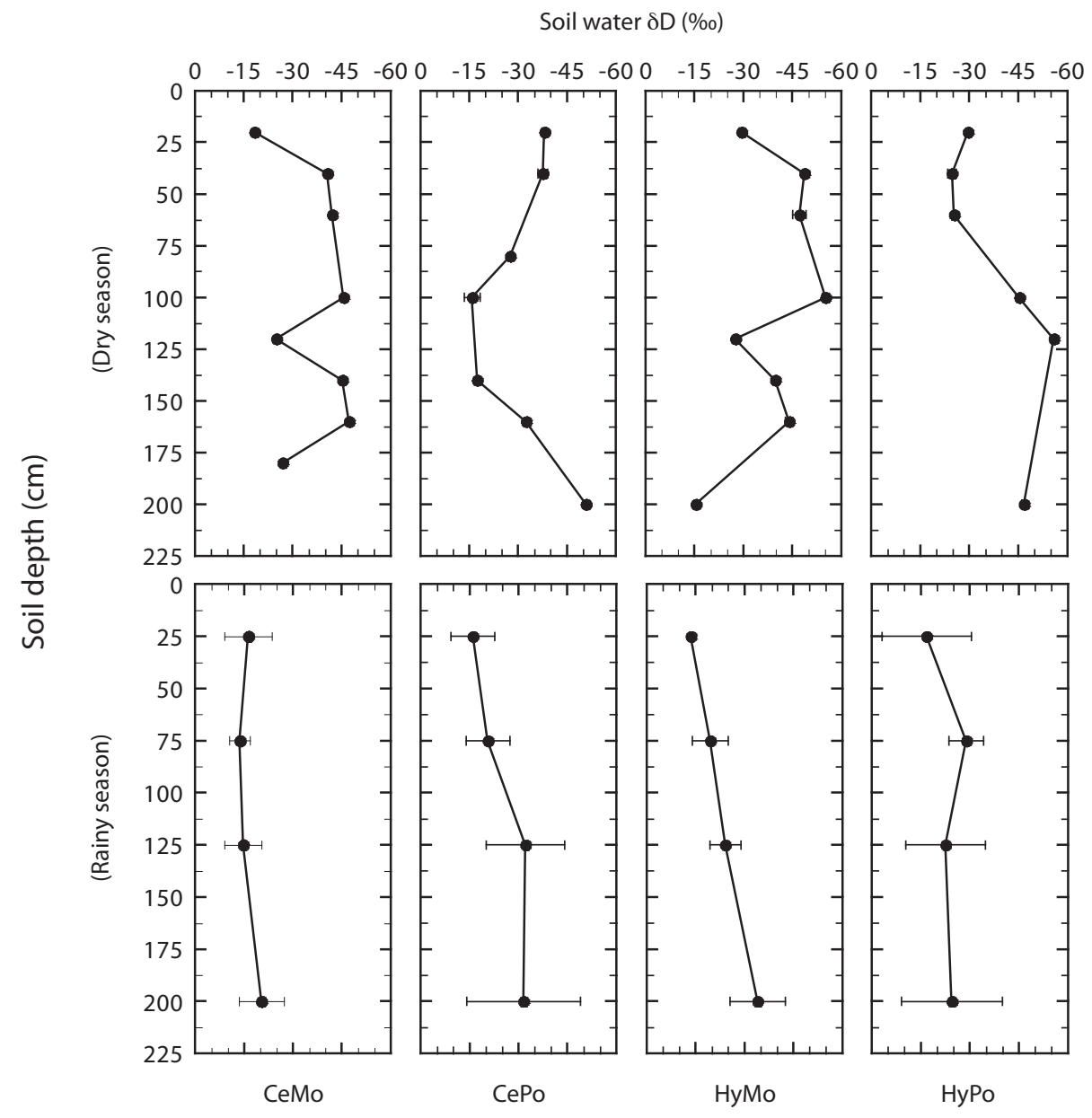

Fig. 2. Soil $\delta \mathbf{D}$ profiles in model 5-y old tropical plant associations during the dry and wet seasons. Each value is the average of three sample locations in each model plant association. CeMo is Cedrela odorata in monoculture, CePo is C. odorata in polyculture, HyMo is Hyeronima alchorneoides in monoculture, HyPo is H. alchorneoides in polyculture.

wet forest soils, provided that the length of the dry period allows continuous soil drying and differential evaporation of water from different layers of the soil profile. Various approaches involving the use of modified isotopic techniques can now be tested under a variety of soil conditions and during longer dry periods. The interactions displayed by the species examined have been characterized as competition in the case of $H$. alchorneoides polycultures, and as complementarity in the case of $C$. odorata polycultures (Haggar and Ewel 1997). The results indicate that the variation in plant water accessed by different species was low, that the plant combinations examined obtained water from more that a single soil layer, or that all of them relied strongly on access to deeper ground water. The presence of the monocotyledons did not affect the pattern of soil water use by the two tree species. Nor were patterns of soil water use by the two monocots affected by the presence of either tree species, perhaps 


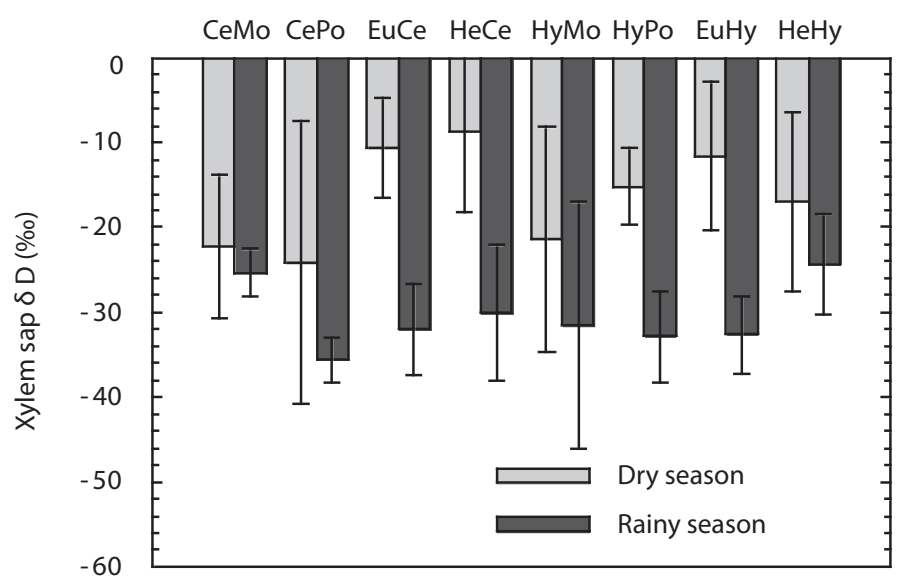

Fig. 3. Xylem sap $\delta \mathbf{D}$ of two tree species and two perennial monocots growing in four model plant associations during the rainy and dry season at La Selva Biological Station. Each value is the average of four samples from each treatment. The plants grew on a well drained, fertile soil. The $60 \times 40 \mathrm{~m}$ stands were composed of fast-growing trees (Hyeronima alchorneoides and Cedrela odorata) planted at a density of 2887 trees $^{-1}$, each tree occupied a hexagonal area of 3.46 $\mathrm{m}^{2}$. H. alchorneoides trees were $8.9 \pm 1.1 \mathrm{~m}$ and $C$. odorata trees were $7.6 \pm 2.3 \mathrm{~m}$ tall at the time of the study. One part of each stand was maintained as a tree monoculture, while the other part was inter-planted with two perennial, large-stature, self-supporting monocotyledons (Euterpe oleracea and Heliconia imbricate). Maximum rooting depth at the time of $\delta \mathrm{D}$ determination was $\sim 2 \mathrm{~m}$ for almost all species, and most roots were concentrated in the upper soil layers. CeMo is Cedrela odorata in monoculture, CePo is C. odorata in polyculture, EuCe is Euterpe oleracea in polyculture with C. odorata, $\mathrm{HeCe}$ is Heliconia imbricata in polyculture with C. odorata, HyMo is Hyeronima alchorneoides in monoculture, HyPo is $H$. alchorneoides in polyculture EuHy is E. oleracea in polyculture with H. alchorneoides and HeHy is H. imbricata in polyculture with $H$. alchorneoides.

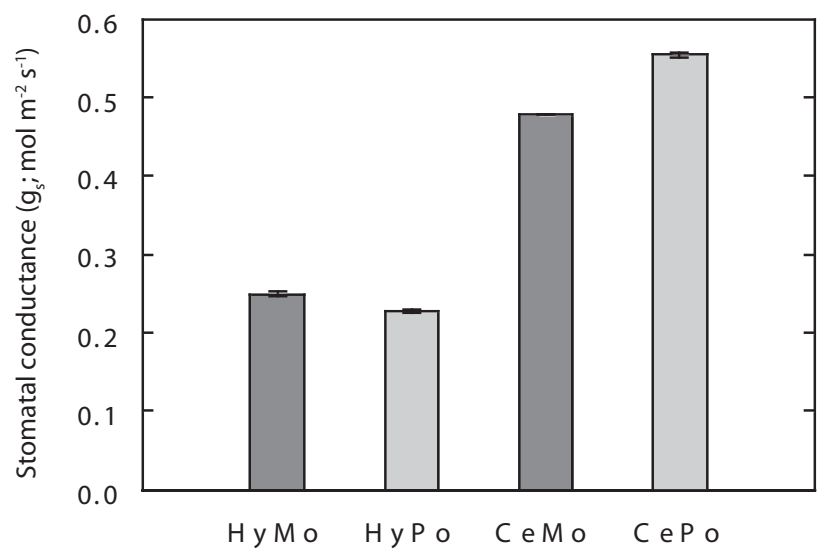

Fig. 4. Stomatal conductance $\left(\mathbf{g}_{\mathbf{s}}\right)$ of $H$. alchorneoides and $C$. odorata trees growing in monoculture and polyculture with a mix of two perennial monocots, E. oleracea and H. imbricata at La Selva Biological Station, Costa Rica. Symbols are as in Figure 1. 
because the monocots (at least E. oleracea) may have reached deeper water-charged soil layers (Haggar and Ewel 1997).

Advantages in soil water acquisition may have been dependent on the fraction of the community leaf area index occupied by each species (Schinning et al. 2002). In addition to belowground processes and root properties that seem to dominate inter-specific relations in plant associations, competition for soil water may be more related to canopy traits that facilitate stem flow and water channeling to the roots, or to rapid responses in leaf gas exchange after episodes of water scarcity. The dense canopy of $H$. alchorneoides seemed determinant in setting this species' dominance over the associated perennial monocots in the plant associations tested. E. oleracea's relative success after canopy elevation in the H. alchorneoides polyculture, coupled with its very deep root system, highlights the importance of canopy as well as temporal factors in modulating the relations between co-existing species over time.

$H$. alchorneoides and $C$. odorata leaves had average life spans of 176 and 50 days, respectively (Hiremath 2000), and leaf traits responsible for longer life span and the evergreen habit may have resulted in reduced $\mathrm{g}_{\mathrm{S}}$ (Sobrado 1991). Evergreen trees that allocate key resources (such as Nitrogen, N) to structural and defensive compounds needed to maintain leaves of greater longevity, may experience a trade-off in $\mathrm{N}$ allocation resulting in lower concentrations of leaf photosynthetic enzymes, higher diffusive resistance to $\mathrm{CO}_{2}$, lower $\mathrm{g}_{\mathrm{S}}$ and reduced rates of photosynthesis. The results indicate that the presence of monocots in the two polycultures did not affect $g_{S}$ of the tree species and therefore was not a factor in competition for soil water. Besides the inherent differences related to their respective phylogeny and phenological habit, $g_{S}$ of trees inter-planted with the perennial monocots did not differ from $\mathrm{g}_{\mathrm{S}}$ of trees growing in monocultures. In fact, Haggar and Ewel (1997) reported that growth and productivity as well as fine root biomass of $C$. odorata trees were increased in polycultures with the perennial monocots, resulting in a complementary interaction; monocot productivity in the $C$. odorata stands was additive to that of the trees (Haggar and Ewel 1997).

The evergreen $H$. alchorneoides, which produced a dense canopy, allocated a large proportion of its biomass and resources to fine root production (Haggar and Ewel 1997), and those roots enabled it to mine the soil for resources and to out-compete inter-planted perennial monocots. Competition for water may become important in shallower soil layers if rapid uptake of rainfall water is required for drought relief, or if rainfall water is channeled preferentially to specific root systems as a consequence of stem flow (Raich 1983). High biomass and resource allocation to fine roots may then be beneficial in capturing limiting water and nutrients such as nitrogen and phosphorus. Thus, under conditions in which water is not the most limiting factor, root-related traits such as rooting depth and nutrient uptake efficiency (Hiremath and Ewel 2001) may still be key to species co-existence. Our results also indicate that the pattern of soil water resources use in these model ecosystems was largely independent of phenological behavior and of the above- and below-ground architecture of the two tree species and the two monocots examined. Under the prevailing environmental conditions of La Selva, water use was determined more by species' attributes (biomass allocation to fine roots and canopy properties) than by water limitations.

High rainfall prevalent in the Costa Rican Atlantic lowlands during most of the year results in sustained high soil water content and in the frequent replacement of soil water. However, short and unpredictable dry periods are frequently the cause of large and rapid drops in soil water content at La Selva. These dry periods are becoming more frequent and may have important consequences for forest functioning and water relations of the vegetation. Under these conditions, the development of gradients in soil water $\delta \mathrm{D}$ signatures is more difficult, and the use of techniques based on isotopic signature of water is limited to dry spells. Other isotopic analyses that use water-labeling 
fronts applied to the soil (Moreira et al. 2000) may be more useful in studying water relations among species in wet ecosystems. Approaches of this kind would also be useful in revealing radial patterns of root distribution, which may override the importance of the soil profile as a water reservoir.

The design of sustainable tropical agroecosystems must be based on the use of particular species and plant combinations, because what is useful in one association and location may be unviable in others. Species mixes may ameliorate stresses such as high temperature and nutrient leaching, frequently associated to the reduced productivity of tropical crops (Corley 1983). Constructing mixed-species communities that imitate natural successional vegetation (Hart 1980) would meet the requisites for sustainable tropical agro-ecosystems: low risk, low nutrient requirements, ability to fully use the available resources, and protection from pests (Ewel 1986, 1999). The isotopic analyses of water uptake and competition for water (Smith et al. 1997, 1998) may therefore be a valuable tool to select species and practices suitable to control the rates and timing of water use of tropical plants in different environments

\section{ACKNOWLEDGMENTS}

This research was supported by grant D/2462-1 from the International Foundation for Science (Sweden) to MarcoV. Gutiérrez-Soto, and support from the U. S. National Science Foundation, the Andrew W. Mellon Foundation, and the U. S. D. A. Forest Service to J. J. Ewel. We acknowledge the assistance of Miguel Cifuentes, Ankila Hiremath, Seth Bigelow, and Proyecto Huertos staff at La Selva Biological Station, OTS. Juan Carlos Rodríguez, Lorena Hernández and Adriana Murillo helped with sample distillation at CIPRONA, Chemistry Department, University of Costa Rica. Instituto Meteorológico Nacional de Costa Rica provided climatic data for La Selva and neighboring sites.

\section{RESUMEN}

Examinamos los patrones de uso de agua del suelo de cuatro asociaciones vegetales establecidas en el Caribe norte de Costa Rica, comparando la composición isotópica del hidrógeno, $\delta \mathrm{D}$, en la savia del xilema y en el agua del suelo en condiciones lluviosas y secas. Estudiamos cuatro asociaciones de cinco años de edad compuestas por dos árboles (Hyeronima alchorneoides y Cedrela odorata) con diferente arquitectura y fenología, cultivados en mono y policultivo con dos monocotiledóneas perennes (Euterpe oleracea y Heliconia imbricata). Las excavaciones mostraron que la profundidad máxima de las raíces fue de 2 $\mathrm{m}$ para casi todas las especies, y que la mayor densidad de raíces se encontraba en la superficie del suelo. La conductividad estomática $\left(\mathrm{g}_{\mathrm{S}}\right)$ fue mayor en el árbol caducifolio $(C$. odorata) que en el perennifolio (H. alchorneoides); dentro de cada especie, $\mathrm{g}_{\mathrm{S}}$ no difirió cuando los árboles fueron cultivados en mono o en policultivo. Los resultados sugieren que: a) las asociaciones examinadas extrajeron agua predominantemente de las capas superficiales del suelo $(<1$ $\mathrm{m})$, b) la variación natural en el acceso al agua del suelo por parte de las especies, y en las propiedades del suelo, fue baja, y c) las combinaciones de plantas obtuvieron agua de varias capas del perfil del suelo simultáneamente. Los factores relacionados con el tiempo fueron importantes en la determinación de las relaciones de competencia y complementariedad observadas entre los árboles y las monocotiledóneas perennes. En las condiciones ambientales prevalecientes, el uso del agua por parte de estas asociaciones de plantas fue determinado más por atributos, como la asignación de biomasa a las raíces finas, la fenología, y las propiedades del dosel, que por limitaciones en la disponibilidad de agua.

Palabras clave: agroecosistemas tropicales, Cedrela odorata, Heliconia imbricata, Euterpe oleracea, Hyeronima alchorneoides, isótopos del agua, monocultivos, policultivos.

\section{REFERENCES}

Ceccon, E., P. Huante \& E. Rincón. 2006. Abiotic factors influencing tropical forest regeneration. Braz. Arch. Biol. Technol. 49: 305-312.

Corley, R.H.V. 1983. Potential productivity of tropical perennial crops. Expl. Agric. 19: 217-237.

Dawson, T.E. 1993. Hydraulic lift and water use by plants: implications for water balance, performance and plant-plant interactions. Oecologia 95: 565-574.

Dawson, T.E. \& J.R. Ehleringer, 1991. Streamside trees that do not use stream water. Nature 350: 335-337. 
Dawson, T.E., S. Mambelli, A.H. Plamboeck, P.H. Templer \& K.P. Tu. 2002. Stable isotopes in plant ecology. Ann. Rev. Ecol. Syst. 33: 507-559.

Drake, P.L. \& P.J. Franks. 2003. Water resource partitioning, stem xylem hydraulic properties and plant water use strategies in a seasonally dry riparian tropical rainforest. Oecologia 137: 321-329.

Ehleringer, J.R. \& T.E. Dawson. 1992. Water uptake by plants: perspectives from stable isotope composition. Plant, Cell \& Environ. 15: 1073-1082.

Ehleringer, J.R. \& C.B. Osmond. 1989. Stable Isotopes, p. 281-300. In R.W. Pearcy, J.R. Ehleringer, H.A Mooney \& P.W. Rundel (eds.). Plant physiological ecology; field methods and instrumentation. Chapman \& Hall, London, England.

Engelbrecht, B.M.J., J.W. Dalling, T.R.H. Pearson, R.L. Wolf, D.A. Gálvez, T. Koehler, M.T. Tyree \& T.A. Kursar. 2006. Short dry spells in the wet season increase mortality of tropical pioneer seedlings. Oecologia 148: 258-259.

Ewel, J.J. 1986. Designing agricultural ecosystems for the humid tropics. Ann. Rev. Ecol. Syst. 17: 245-271.

Ewel, J.J. 1999. Natural systems as models for the design of sustainable systems of land use. Agroforestry Syst. 45: 1-21.

Gliessman, S.R. 1986. Plant interactions in multiple cropping systems, p. 82-95 In C.A. Francis (ed.). Multiple cropping systems. McMillan, New York, USA.

Goldstein, G., F.C. Meinzer, L. Sternberg, P. Jackson, J. Cavelier \& N.M. Holbrook. 1996. Evaluating aspects of water economy and photosynthetic performance with stable isotopes from water and organic matter, p. 244-267. In S.S. Mulkey, R.L. Chazdon \& A.P. Smith. (eds.). Tropical forest plant ecophysiology. Chapman \& Hall, New York, U.S.A.

Gutiérrez, M.V. \& L.S. Santiago. 2006. A comparison of sap flow measurements and potometry in two tropical lowland tree species with contrasting wood properties. Rev. Biol. Trop. 54(1): 73-81.

Haggar, J.P. \& J.J. Ewel. 1995. Establishment, resource acquisition, and early productivity as determined by biomass allocation patterns of three tropical tree species. For. Sci. 41: 689-708.

Haggar, J.P. \& J.J. Ewel. 1997. Primary productivity and resource partitioning in model tropical ecosystems. Ecology 78: 1211-1221.
Hart, R.D. 1980. A natural ecosystem analog approach to the design of successional crop systems for tropical forest environments. Biotropica 12: 73-82.

Hiremath A.J. \& J.J. Ewel. 2001. Ecosystem nutrient use efficiency, productivity, and nutrient withdrawal in model tropical communities. Ecosystems 4: 669-682.

Hiremath AJ. 2000. Photosynthetic nutrient-use efficiency in three fast-growing tropical trees with differing leaf longevities. Tree Physiol. 20: 937-944.

Jackson, P.C., J. Cavelier, G. Goldstein, F.C. Meinzer \& N.M. Holbrook. 1995. Partitioning of water resources among plants of a lowland tropical forest. Oecologia 101: 197-293.

Jackson, P.C., F.C. Meinzer, M. Bustamante, G. Goldstein, A. Franco, P.W. Rundel, L. Caldas, E. Igler \& F. Causin. 1999. Partitioning of soil water among tree species in a Brazilian Cerrado ecosystem. Tree Physiol. 19: 717-724.

Little, R.C., R.J. Freund, \& P.C. Spector. 1992. SAS systems for linear models. SAS Institute, Chicago, USA.

McDade, L.A., K.S. Bawa, H.A. Hespenheide \& G.S. Hartshorn. 1994. La Selva, ecology and natural history of a Neotropical rain forest. Univ. Chicago, Chicago, USA.

Meinzer, F.C., J.L. Andrade, G. Goldstein, N.M. Holbrook, J. Cavelier \& S.J. Wright. 1999. Partitioning of water resources among canopy trees in a seasonally dry tropical forest. Oecologia 121: 293-301.

Mesquita R., K. Ickes, G. Ganade \& B. Williamson. 2001. Alternative successional pathways in the Amazon Basin. J. Ecol. 89: 528-537.

Moreira, M.Z., L. d S. Sternberg \& C. Nepstad. 2000. Vertical patterns of water uptake by plants in a primary forest and an abandoned pasture in the eastern Amazon: an isotopic approach. Plant and Soil 222: 95-107.

Nepstad, D.C., C.R. Carvalho, D.A. Davidsno, P.H. Jipp, P.A. Lefebre, G.H. Negreiros, E.D. Silva, T.A. Stone, S.E. Trumbore \& S. Vieira. 1994. The role of deep roots in the hydrological and carbon cycles of Amazonian forests and pastures. Nature 372: 666-669.

Ong, C.K. 1995. The "dark side" of intercropping: manipulation of soil resources, p. 45-66 In H. Sinoquet \& P. Cruz (eds.). Ecophysiology of tropical intercropping. INRA, Versailles, France. 
Pate J.S. \& T.E. Dawson. 1999. Assessing the performance of woody plants in uptake and utilization of carbon, water and nutrients. Implications for designing agricultural mimic systems. Agrofor. Syst. 45 :245-275.

Raich, J.W. 1983. Throughfall and stem flow in mature and year-old wet tropical forest trees. J. Trop. Ecol. 24: $234-243$.

Sánchez, P.A. 1976. Multiple cropping: an appraisal of present knowledge and future research needs, $\mathrm{p}$. 373-378. In R.A. Papendick, P.A. Sanchez \& G.B. Tripplet (eds.). Multiple Cropping. ASA-CSSASSSA, Madison, Wisconsin, USA.

Schinning, S. K. Davis, L. Richardson \& J.R. Ehleringer. 2002. Deuterium enriched irrigation indicates different forms of rain use in shrub/grass species of the Colorado Plateau. Oecologia 130: 345-355.

Smith, D.M., P.G. Jarvis \& J.C.W. Odongo. 1997. Sources of water used by trees and millet in Sahelian windbreak systems. J. Hydrol. 198: 140-153.

Smith, D.M., P.G. Jarvis \& J.C.W. Odongo. 1998 Management of windbreaks in the Sahel: the strategic implications of tree water use. Agrof. Syst. 40: 83-96.

Snaydon, R.W. 1991. Replacement or additive designs for competition studies? J. Appl. Ecol. 26: 1043-1047.

Sobrado, M.A. 1991. Cost-benefit relationships in deciduous and evergreen leaves of tropical dry forest species. Funct. Ecol. 5: 608-616.

Sternberg, L. d SL., M.Z. Moreira \& D.C. Nepstad. 2002. Uptake of water by lateral roots of small trees in an Amazon tropical forest. Plant and Soil 238: 151-158.
Stratton L.C., G. Goldstein \& F.C. Meinzer. 2000. Temporal and spatial partitioning of water resources among eight woody species in a Hawaiian dry forest. Oecologia 124:309-317.

Swaine, M.D. 1996. Foreword. p. 21-28. In M.D. Swaine (ed.). The ecology of tropical forest tree seedlings. Parthenon Publishing, Midsomer Northon, England.

Thorburn, P.J. \& J.R. Ehleringer. 1995. Root water uptake of field-growing plants indicated by measurements of natural-abundance deuterium. Plant and Soil 177: 225-233.

Topp, G., J. Davis \& P. Annan. 1980. Electromagnetic determination of soil water content: measurements in coaxial transmission lines. Water Resour. Res. 16: 574-582.

Walker, C.D. \& S.B. Richardson. 1991. The use of stable isotopes of water in characterizing the source of water in vegetation. Chem. Geol. 94: 145-158.

White, J.W.C., E.R. Cook, J.P. Lawrence \& W.S. Broecker. 1985. The $\mathrm{D} / \mathrm{H}$ ratios of sap in trees: implications for water use and tree ring $\mathrm{D} / \mathrm{H}$ ratios. Geochim. Cosmochim. Acta 49: 237-246.

Whitmore, T.C. 1996. A review of some aspects of tropical rain forest seedling ecology with suggestions for further enquiry, p. 3-40. In M.D. Swaine (ed.). The ecology of tropical forest tree seedlings. Parthenon Publishing, Midsomer Northon, England.

Wright, S.J., C. Carrasco, O. Calderón \& S. Paton. 1999. The El Niño southern oscillation, variable fruit production, and famine in a tropical forest. Ecology 80: 1632-1647. 
